\title{
A Tripadvisor kiemelt turisztikai fejlesztési térségekre vonatkozó vendégelégedettségi adatainak elemzése
}

\author{
Szerzők: Mártonné Máthé Kinga ${ }^{1}$ - Simonyi Norbert ${ }^{2}$
}

Az elsôsorban amerikai és európai utazók által használt, több mint 500 millió értékelést tartalmazó Tripadvisor vendégelégedettségi és visszajelzési adataiból nyert mutatószámok több esetben egybecsengenek mind a KSH turisztikai vendégforgalmi számaival, mind a Magyar Turisztikai Ügynökség saját kutatásaival és adataival. Általánosságban elmondható, hogy szoros összefüggés van az értékelések minôsitése és a vendégszám alakulása között, azaz a több és jobb értékelést kapott desztinációkban magasabb a turistaforgalom, ami fordítva is igaz. A tanulmány arra is rávilágít, hogy a Nemzeti Turizmusfejlesztési Stratégia (NTS) térségi lehatárolása, célrendszere, pillérei és horizontális célkitúzései döntően megfeleltethető́k a Tripadvisor használók szubjektív elvárásainak, problémafelvetéseinek és a bejegyzések területi eloszlásának. Mindezekból következően a már kijelölt, illetve a továbbiakban kiemelni tervezett turisztikai fejlesztési térségek esetében fontos adatokhoz és visszajelzésekhez jutottunk a szükséges beavatkozások mélységét és irányát tekintve.

Kulcsszavak: Tripadvisor, vendégelégedettség, desztináció, attrakció, értékelés.

\section{Bevezetés}

Az interaktív, vendégelégedettséget mutató, azt valós időben fel is dolgozó utazási portálok az elmúlt években egyre jelentősebb hatást gyakorolnak az utazási motivációra, illetve jelentős szerepük van az utazási desztináció kiválasztásánál is. A megszokott „marketingszövegek” helyett a vendégelégedettségi kommentek olvasásakor legtöbbször igazi, hús-vér turistától származó, szubjektív értékeléshez juthat az utazó. Fejlettebb esetben kommunikáció alakul ki az így értékelt helyszíngazda, a volt látogatók és az utazni vágyók között. Ez a háromoldalú kommunikáció mind az utazókat, mind a helyszíngazdákat valós idejú és teljesen reális információhoz juttatja, ami a közösségi médiafelületek megjelenése elótt gyakorlatilag lehetetlen volt. Más kérdés, hogy a helyszínek ezeket az információkat mennyire építik be mindennapjaikba, akár az adott attrakció üzemeltetésébe, kommunikációjába, akár a kontrolling-visszacsatolási tevékenységükbe. Jelenleg még igen kevés magyarországi turisztikai attrakció menedzsmentje használja fel

\footnotetext{
1 igazgató, Kisfaludy2030 Turisztikai Fejlesztő Nonprofit Zrt., Aktív turisztikai és program koordinációs igazgatóság, kinga.mathe@kisfaludy2030.hu 2 kiemelt vezető szakértő, Magyar Turisztikai Ügynökség Zrt., Turizmus stratégiai vezérigazgató-helyettes terület, Turizmus szakmai igazgatóság, norbert.simonyi@mtu.gov.hu
}

ezeket az információkat, felületeket a saját tevékenysége során. Csak elvétve lehet találkozni a fent említett hármas kommunikációval, a világon már gyakorlattá vált közösségi média felületekkel foglalkozó munkavállaló a hazai attrakciók tekintetében még viszonylag ritka. Amennyiben mégis van erre dedikált kolléga, akkor általában a saját mindennapi munkája mellett végzi ezt a feladatot.

A professzionális hozzáállás ezekhez a felülethasználatokhoz hazánkban még kezdetleges. Az 1. táblázat a hazai kiemelt és kiemelni kívánt turisztikai fejlesztési térségekben mutatja a hármas kommunikáció meglétét.

A tanulmány a hivatalos hazai turisztikai adatok és a Tripadvisor felületeiról nyerhetô statisztikák közötti megfeleltetéseket vizsgálja, különös tekintettel a jelenleg már elfogadott, illetve a még kidolgozás alatt álló kiemelt turisztikai fejlesztési térségekre. Összességében elmondható, hogy a hazai attrakciók rendkívül kismértékú és legtöbb esetben hiányos értékelései, kommentjei alapján készített statisztikai adatbázis számai több esetben megfeleltethetőek a hivatalos hazai vendégforgalmi adatoknak, ez az összevetés markáns kapcsolatot mutat. A legfontosabb kérdések, amelyekre választ keres a tanulmány, hogy a vendégek szubjektív véleménye alapján lehet-e térségi és országos szinten egyaránt objektív jellemzóket meghatározni, és hogy az egyedi attrakcióra reflektáló vendégkomment igaz-e a térségre is? A tanulmány több témakört határoz meg az egyedi attrakciókhoz 
A nevesített és a még nem nevesített kiemelt turisztikai fejlesztési térségek hármas kommunikációja

\begin{tabular}{|l|c|c|}
\hline & $\begin{array}{c}\text { Van-e olyan attrakció, ahol az attrakció } \\
\text { és a látogató közötti kommunikáció } \\
\text { megvalósul? }\end{array}$ & $\begin{array}{c}\text { Van-e olyan attrakció, ahol a látogatók } \\
\text { egymás közötti kommunikációja } \\
\text { megvalósul? }\end{array}$ \\
\hline Bakony & nincs & nincs \\
\hline Balaton & nincs & van \\
\hline Budapest agglomeráció & van & van \\
\hline Bükk & van & van \\
\hline Debrecen és Hajdúszoboszló & nincs & van \\
\hline Dunakanyar & nincs & van \\
\hline Felsó-Tisza & nincs & nincs \\
\hline Gyula és térsége & van & van \\
\hline Kaposvár-Zselic & nincs & nincs \\
\hline Köszeg-Sárvár & nincs & van \\
\hline Mátra & van & van \\
\hline Örség & nincs & nincs \\
\hline Nyírség & nincs & van \\
\hline Pécs-Villány-Ős-Dráva & nincs & nincs \\
\hline Sopron-Fertón & nincs & nincs \\
\hline Szeged-Makó & nincs & nincs \\
\hline $\begin{array}{l}\text { Szigetköz-Győr- } \\
\text { Pannonhalma }\end{array}$ & nincs & nincs \\
\hline Tisza-tó és Hortobágy & nincs & nincs \\
\hline Tokaj-Zemplén & nincs & nincs \\
\hline
\end{tabular}

Forrás: saját szerkesztés

történő hozzászólások alapján, amelyek általánosíthatók térségi szinten is. Ilyenek a családbarát szolgáltatások, az infrastrukturális hiányosságok, a megközelíthetőség kérdése, a tisztaság illetve a személyzet viselkedése és nyelvtudása.

\section{Módszertan}

Adatbázist készítettünk a Tripadvisor 2017. II. félévi adatai alapján, amely tartalmazza az elfogadott és elfogadásra váró kiemelt turisztikai fejlesztési térségek településeit és turisztikai attrakcióit, ezek Tripadvisor értékeléseit, nyelvi mutációk szerinti hozzászólásait és értékelési pontszámait. Ezek az adatok kerültek összehasonlításra és megfeleltetési vizsgálatra a KSH 2016. évi vendégforgalmi és a Magyar Turisztikai Ügynökség (MTÜ) 2016. évi saját gyújtésú adataival. Korrelációs elemzést és trendvizsgálatot is végeztünk minden térség esetében. A nyelvek és nemzetiségek összehasonlításakor a kommentelés nyelvei és a hozzászólók nemzetisége súlyozva szerepelt. 3-as értéket kaptak az első helyen szereplő nyelvek, 2-est a másodikon, 1-est a harmadikon, a többi 0-át, és az összeseikből került kiszámításra a korreláció. A KSH adatok közül felhasználásra került a kiemelt térségek kereskedelmi szálláshelyeinek külföldi és belföldi vendégszáma és a küldő országok adatai. Az MTÜ saját adatbázisának alapja a kiemelt térségek attrakcióinak száma település szintú bontásban, illetve az ezekhez köthetó látogatóforgalmi adatok (2. táblázat).

A Tripadvisor adatbázis adatcsoportjai a következők voltak: desztináció, település, helyezés, magyar értékelések száma, külföldi értékelések száma, összes értékelés száma, osztályozások (\%) (kiváló, nagyon jó, átlagos, gyenge, szörnyú), pontszám, legtöbb bejegyzés nyelve, legtöbb bejegyzés nyelve (db), második legtöbb bejegyzés nyelve, második legtöbb bejegyzés nyelve (db), harmadik legtöbb bejegyzés nyelve, harmadik legtöbb bejegyzés nyelve (db), egyéb nyelvre vonatkozó megjegyzések, jellemző hiba, létező hiba, pozitív megítélések, általános megjegyzés. 
A Tripadvisor, a KSH és a MTÜ adatainak egymáshoz viszonyított összefüggései

\begin{tabular}{|c|c|c|}
\hline & \multicolumn{2}{|r|}{ Kapcsolat erôssége } \\
\hline Tripadvisor átlag pontszám/kereskedelmi szálláshely vendégszám & $-0,15$ & $\begin{array}{l}\text { gyenge, majdnem hanyagolható } \\
\text { kapcsolat }\end{array}$ \\
\hline Tripadvisor átlag pontszám/attrakciók látogatószáma & 0,00 & $\begin{array}{c}\text { gyenge, majdnem hanyagolható } \\
\text { kapcsolat }\end{array}$ \\
\hline $\begin{array}{l}\text { Tripadvisor értékelések száma/kereskedelmi szálláshely } \\
\text { vendégszám }\end{array}$ & 0,85 & $\begin{array}{l}\text { magas korreláció, markáns } \\
\text { kapcsolat }\end{array}$ \\
\hline Tripadvisor értékelések száma/MTÜ attrakciók látogatószáma & 0,88 & $\begin{array}{l}\text { magas korreláció, markáns } \\
\text { kapcsolat }\end{array}$ \\
\hline Tripadvisor/KSH külföldi arány & 0,38 & biztos, de gyenge kapcsolat \\
\hline Tripadvisor attrakciószám/KSH vendégszám & 0,78 & $\begin{array}{c}\text { magas korreláció, markáns } \\
\text { kapcsolat }\end{array}$ \\
\hline Tripadvisor attrakciószám/MTÜ attrakciók látogatószáma & 0,78 & $\begin{array}{l}\text { magas korreláció, markáns } \\
\text { kapcsolat }\end{array}$ \\
\hline Tripadvisor településszám/MTÜ telepiülésszám & 0,86 & $\begin{array}{c}\text { magas korreláció, markáns } \\
\text { kapcsolat }\end{array}$ \\
\hline Tripadvisor attrakciószám/MTÜ attrakciószám & 0,52 & közepes korreláció, jelentôs kapcsolat \\
\hline $\begin{array}{l}\text { Tripadvisor kiváló értékelések aránya/KSH kereskedelmi szálláshely } \\
\text { vendégszám }\end{array}$ & 0,09 & $\begin{array}{c}\text { gyenge, majdnem hanyagolható } \\
\text { kapcsolat }\end{array}$ \\
\hline $\begin{array}{l}\text { Tripadvisor értékelések nyelve/ KSH kereskedelmi szálláshely } \\
\text { vendégszáma nemzetiségek szerint }\end{array}$ & 0,54 & közepes korreláció, jelentôs kapcsolat \\
\hline Tripadvisor kiváló értékelések aránya/MTÜ látogatószám & 0,22 & biztos, de gyenge kapcsolat \\
\hline
\end{tabular}

Forrás: saját szerkesztés

\section{A kiemelt turisztikai fejlesztési térségek elemzése}

A cikk szövegének lezárásáig a Balaton (1861/2016. (XII.27.) Korm. határozat), Sopron-Fertố (1862/2016. ( XII.27.) Korm. határozat), Tokaj, Felsố-Tisza és Nyírség (1092/2017. (II.21.) Korm. határozat), Dunakanyar (1550/2017. (VIII.18.) Korm. határozat), és Debrecen, Hajdúszoboszló, Hortobágy, Tisza-tó (1522/2017. (VIII.14.) Korm. határozat) kiemelt turisztikai fejlesztési térségek kerültek nevesítésre és lehatárolásra. További térségek kijelölése van folyamatban a turisztikai térségek fejlesztésének állami feladatairól szóló 2016. évi CLVI. törvény alapján. A tanulmány az 5 nevesített térségen kívül az MTÜ által elókészítés alatt álló térségeket is tartalmazza, amelyek lehatárolása, száma és nevesítése még nem került elfogadásra. A következőkben alfabetikus sorrendben mutatjuk be röviden a térségek vendégelégedettségi és $\mathrm{KSH}$ mutatóinak összehasonlító elemzését.

\subsection{BAKONY TÉRSÉGE}

A desztináció átlagos településszám mellett az átlagnál jóval kevesebb értékelt vonzerôvel és értékeléssel rendelkezik. A külföldi értékelők és a kiváló értékelések aránya magasabb, mint az átlag, az átlagos értékelési pontszám minimálisan haladja meg az átlagértéket. A kiemelt desztinációk közül a kereskedelmi szálláshelyek vendégforgalmi adatai a Felső-Tisza után a legalacsonyabbak, a külföldi vendégarány átlagos. A desztináció attrakcióinak átlagos látogatószáma a harmada a többi desztináció átlagos látogatószámának, és a településszám is alacsonyabb. A kiemelt térség attrakcióinak és településeinek negyede rendelkezik Tripadvisor értékeléssel, ami a települések tekintetében 25\%-kal a pozitív irányban, míg az attrakciók tekintetében 10\%-kal a negatív irányban tér el az átlagostól, tehát inkább a települések és nem az attrakciók tekintetében mutat értékelési aktivitást. Összességében a desztináció az átlagos településszám mellett alacsony volumenú turisztikai potenciált mutat átlagos pontszámmal, de az átlagosnál magasabb külföldi értékelésszámmal. A kiváló értékelések száma magas, és a szolgáltatások színvonalának erôteljesebb szórását mutatja.

\subsection{BALATON TÉRSÉGE}

A Balaton a legtöbb értékelt településsel és a második legtöbb (Bükk után) értékelt attrakcióval rendelkezik. $\mathrm{Az}$ értékelések száma négyszeresen haladja meg 
az összes kiemelt desztináció átlagát, a külföldi értékelók aránya 10 százalékponttal magasabb az átlagnál, az átlagpontszám átlagos, viszont a kiváló értékelések száma magas, és a szolgáltatások színvonalának erőteljesebb szórását mutatja. Az átlagos vendégforgalmi adat a hatszorosa a kiemelt turisztikai fejlesztési térségek átlagának, a külföldi arány átlagos. A desztináció attrakcióinak száma és összes látogatószáma 5-6-szorosa az átlagnak. Mind az értékelt településeknek, mind az attrakcióknak mindössze 10\%-a került értékelésre a Tripadvisor-on, amely arány $25-50 \%$ ponttal kevesebb az átlagnál. Összességében elmondható, hogy hatalmas volumenben, de változatos minőségben rendelkezik turisztikai attrakciókkal a térség, mely a negyedik legtöbb kiváló értékeléssel rendelkezik. Bár ez a desztináció mondhatja magáénak a legtöbb értékelt települést és a második legtöbb értékelt attrakciót, mégis alacsony az értékelt települési és attrakciós arány, mivel ez a desztináció rendelkezik a legtöbb településsel és attrakcióval.

\subsection{BUDAPEST AGGLOMERÁCIÓ TÉRSÉGE}

Budapest agglomerációja mind az értékelt települések számát, mind az attrakciószámot tekintve messze az átlag fölötti értékkel rendelkezik. Az értékelések átlagpontszáma viszont a legalacsonyabb, és a kiváló értékelések száma is átlag alatti. A külföldi értékelések száma a harmadik legtöbb a desztinációk között. A kereskedelmi szálláshelyek vendégforgalmi adatai megfelelnek az átlagnak. $A$ turisztikailag releváns attrakciók száma a kétszerese, a látogatószám viszont fele az átlagnak, a településszám pedig kissé átlag feletti a többi desztinációhoz képest. Az értékelt településszám magas, viszont az értékelt attrakciószám aránya az összes turisztikailag releváns attrakció arányához képest közel 40\%-kal alacsonyabb. Összességében elmondható, hogy magas külföldi értékelési aránnyal gyenge minôséget képvisel. Sok attrakció jellemzi a térséget, viszont ehhez képest nagyon alacsony a látogatószám, melyból adódóan a turisztikailag releváns attrakciók értékelési aránya is rendkívül alacsony.

\subsection{BÜKK TÉRSÉGE}

A Bükk desztináció rendelkezik a harmadik legtöbb értékelt településsel és messze a legtöbb értékelt attrakcióval. Az értékelések száma a Balaton után a második legtöbb. A külföldiek aránya, az értékelés átlagpontszáma és a kiváló értékelések aránya átlagos. A kereskedelmi vendégszám a kétszerese az átlagnak, alacsony külföldi részaránnyal. A desztináció település és turisztikai attrakciószáma alacsony, viszont a látogatószám a duplája az át- lagosnak. Az értékelt település és attrakció arány messze meghaladja a többi térség értékét. Összességében elmondható, hogy a kiemelt fejlesztési térség az átlagosnál kevesebb turisztikai attrakcióval rendelkezik, viszont ezek a vonzerők jelentős látogatószámot generálnak, illetve a látogatók körében elérik azt az ingerküszöböt, hogy értékeljék azokat, és ami a legfontosabb, nem azért, mert rossz a szolgáltatás minősége. A Bükk desztináció a vendégértékelések alapján az egyik legtrendibb hely Magyarországon, amely még épp elég „egzotikus” ahhoz, hogy megosztásokat és értékeléseket generáljon. Turisztikai potenciálja messze meghaladja a többi fejlesztési térségét, ezen kívül az attrakciók koncentráltan helyezkednek el egy viszonylag kis területen, amely elősegíti a turisztikai látogatásokat.

\subsection{DEBRECEN ÉS HAJDÚSZOBOSZLÓ TÉRSÉGE}

Összességében elmondható, hogy a térségben kevés az értékelt település, viszont az értékelt attrakciók száma a duplája az átlagnak. Az értékelések száma és a külföldiek részaránya átlag feletti, az értékelési pontszámok átlagosak. A külföldiek aránya a kereskedelmi szálláshelyeken átlagos, viszont az összes vendégforgalmi adat magasabb az átlagnál. A települések és az attrakciók ebben a desztinációban kerülnek legnagyobb részarányban értékelésre, és a látogatószám bóven meghaladja az átlagot. Ez a desztináció is fókuszált turisztikai kínálattal rendelkezik, amelynek legnagyobb része a Tripadvisor értékelésében is szerepel. A desztináció kevés településen, kis mennyiségú, de országos jelentôségú turisztikai és értékelt attrakcióval jellemezhetố átlagos minőséggel.

\subsection{DUNAKANYAR TÉRSÉGE}

A Dunakanyar térség rendelkezik a második legmagasabb részarányú külföldi értékeléssel és összességében a harmadik legtöbb értékeléssel. Az értékelt településszám átlagos, viszont az értékelt attrakciók száma magas, az értékelések pontszáma pedig átlagos. Érdekes, hogy a magas külföldi értékelés nem jelentkezik a kereskedelmi szálláshely vendégforgalmi adatainál, tehát vagy Szlovákiából egynapos kirándulók, vagy Budapesten megszálló külföldiek jelentik a magas részarányt. A térség összes település és attrakciószáma a duplája az átlagnak, ezzel együtt ugyanilyen arányban magasabb a turisztikai attrakciók összlátogatószáma is. Mivel az értékelt települések és attrakciók száma átlagos, viszont az összes attrakció és településszám magas, így az értékelt település arány a legalacsonyabb, és az értékelt attrakció arány is $20 \%$-kal ala- 
csonyabb az átlagnál. Ez a desztináció rendelkezik arányaiban a legtöbb nem értékelt településsel. Az értékelt települések és az ott található attrakciók adatai meghaladják az átlagot, különösen erős értékelés mellett, amelynek külföldi részaránya is kiemelkedően magas.

\subsection{FELSÖ-TISZA TÉRSÉGE}

A Felső-Tisza fejlesztési térség minimális értékelt város és attrakciószámmal jellemezhető, ahol az értékelések száma is mindösszesen 13 darab. A kiváló értékelések részaránya a legkevesebb, nagyságrendjét tekintve azonos a Tisza-tó és Hortobágy térséggel. A kereskedelmi szálláshelyek vendégforgalmi adatai is minimális volument mutatnak. Az attrakciók látogatószáma 20\%-a a többi kiemelt fejlesztési térség átlagos látogatószámának, viszont a települések és az attrakciók száma nem sokkal marad el az átlagtól. Az értékelt település és attrakció arányban az Ôrség előtt, az utolsó előtti helyen szerepel. Összességében elmondható, hogy minimális az értékelések száma és ezek pontszáma is alacsony, főleg a kiváló minőségú attrakciók hiánya emelendő ki. Ez az érdektelenség és negatív vélemény a turisztikai attrakciók látogatószámában is megfigyelhető.

\subsection{GYULA ÉS TÉRSÉGE}

Mivel a kiemelni tervezett turisztikai fejlesztési térség gyakorlatilag két várost tartalmaz, így természetesen a két értékelt település messze az átlag alatti számot eredményez. Amennyiben viszont az értékelt turisztikai attrakciókat arányosítjuk a településszámhoz, úgy már átlag feletti értéket kapunk. Ugyanez a helyzet az értékelések számánál is. Mind az értékelés átlagpontszáma, mind pedig a kiváló értékelések aránya átlag közeli. Ugyancsak a minimális településszám miatt a kereskedelmi szálláshely mutatók is alacsony volumenúek, illetve az ezeket igénybe vevő külföldi vendégek részaránya is messze átlagon aluli. A turisztikailag releváns attrakciók száma szintén elenyésző, így a fejlesztési térség minden szempontból túl kisméretü, hogy bármilyen általános következtetést levonhassunk az adatokból.

\subsection{KAPOSVÁR-ZSELIC TÉRSÉGE}

Kaposvár-Zselic kiemelni kívánt turisztikai fejlesztési térség adataiból, mindenfajta arányosítás ellenére sem lehet következtetéseket levonni. A két település és attrakció, valamint az értékelések minimális száma a Felsô-Tisza és az Ôrség után itt a legkevesebb, viszont ez a kevés értékelés a második legmagasabb külföldi arányt mutatja a Szigetköz-Győr-Pannonhalma térség után. A térség, ugyancsak a Felső-Tisza után, a második legalacsonyabb turisztikai attrakciós látogatószámmal rendelkezik, viszont ellentétben Gyula térségével, amelynél hasonlóan alacsonyak az adatok, itt még az értékelt települések és attrakciók aránya is alacsony, így az adatokból ebben a térségben lehet a legkevesebb következtetést levonni. Összességében elmondható, hogy a térség alacsony turisztikai volumene teljes érdektelenséggel párosul a belföldi Tripadvisor használók körében, mivel az a néhány értékelés is, ami rendelkezésre áll, 83\%-ban külföldiektől (vélhetően a Balaton déli partján tartózkodó és a térségbe látogató) származik.

\subsection{KÖSZEG-SÁRVÁR TÉRSÉGE}

A térség 6 települése és 13 attrakciója összesen 529 értékelést kapott. Az első két adat kis mértékben kevesebb az átlagosnál, az értékelések száma viszont fele a többi térség átlagos értékelési számának. A külföldi értékelések száma átlagon felüli, viszont a pontszámok és a kiemelkedő attrakciók száma elmarad az átlagtól. A kereskedelmi szálláshelyek vendégszáma átlag alatti, viszont a külföldi vendégszám aránya duplája a többi térség átlagos arányszámának. A kevés település kevés turisztikai attrakciót is jelent, amelyeknek több mint a fele nincs értékelve. Összességében elmondható, hogy a desztináció kis turisztikai volumennel rendelkezik, átlagos adatokkal és magas külföldi részaránynyal.

\subsection{MÁTRA TÉRSÉGE}

A Mátra térség értékelési adatai megfelelnek az átlagnak. Az átlagok tekintetében fontos kiemelni, hogy minimális a külföldi értékelések száma, messze ebben a desztinációban a legmagasabb a magyar értékelői részvétel. Ugyanez a belföldi dominancia érvényesül a kereskedelmi szálláshelyek vendégforgalmának tekintetében is, bár alacsonyabb volumen mellett. A térségben található települések száma megfelel az átlagnak, a turisztikai attrakciók száma viszont az átlag kevesebb, mint 40\%-a, mégis az attrakciók átlagos látogatószáma meghaladja az átlagot. Összességében elmondható, hogy a Mátra térség kifejezetten belföldi desztináció, ennek minden pozitív és negatív jellemzójével. Sok településen elszórtan helyezkednek el az attrakciók magas látogatószámmal, és az átlagnál magasabb elégedettségi szinttel. Inkább az egynapos utazások tekintetében jelent jelentős turisztikai vonzerót. 


\subsection{MURA-ŐRSÉG TÉRSÉGE}

A Tripadvisor értékeléseknek mind abszolút, mind arányszámában az átlag alatti jellemzókkel rendelkezik e kiemelni tervezett turisztikai fejlesztési térség. A Tisza-tó és Hortobágy után itt a második legkevesebb a kiváló értékelések aránya, ezen kívül a külföldi értékelések száma is kifejezetten alacsony. Ehhez hasonlóan a kereskedelmi szálláshelyek vendégforgalmi adatai is alacsony értékeket mutatnak, viszont a külföldi vendégek részaránya a negyedik legmagasabb. Mind a települések száma, mind az attrakciók száma meghaladja az átlagot, ellenben a látogatószám negyede a többi desztináció átlagának. Mivel sok apró, kis vendégszámmal jellemezhetố attrakció alkotja a térséget és az értékelési volumen alacsony, így ez a térség rendelkezik a legkisebb attrakció/értékelés és település/értékelés aránnyal.

\subsection{NYÍRSÉG TÉRSÉGE}

A Nyírség kiemelt turisztikai fejlesztési térségben egy település három attrakciója került értékelésre a Tripadvisor-on. A külföldi részarány alacsony, viszont mind az értékelések átlagpontja, mind a kiváló értékelések aránya at legjobb a desztinációk között. A térség vendégszáma a harmada, külföldi vendégszáma a fele az átlagnak, melyből következik, hogy a külföldi részarány magasabb, mint a többi térségben. A turisztikai attrakciókat tekintve mind a település, mind az attrakció, mind pedig a látogatószám messze elmarad az átlagtól. Az értékelési és az attrakciós adatok következményeként az értékelési arányok is alacsonyak. Összességében elmondható, hogy mind az utazási, mind az értékelési hajlandóság kicsi, viszont aki járt a desztinációban, az átlagnál jóval magasabb pontszámot adott az attrakciók minőségére, mint a többi térségben.

\subsection{PÉCS-VILLÁNY-ŐS-DRÁVA TÉRSÉGE}

A Pécs-Villány-Ốs-Dráva kiemelni tervezett turisztikai fejlesztési térség esetében a Tripadvisor értékelő aktivitást mutató adatai az átlagnál minimálisan magasabb adatokat, míg a minóségi értékelések minimálisan alacsonyabb értéket mutatnak. A KSH vendégforgalmi adatai, összehasonlítva a többi kiemelt régióval, 30\%-kal alacsonyabb értékeket mutatnak, ami igaz mind a belföldi, mind a külföldi forgalmi adatokra. A desztináció attrakcióinak és településeinek a száma az átlaghoz képest 10\%-os különbséget mutat negatív irányban. Az értékelések minimálisan magasabb, illetve az attrakciós adatok minimálisan alacsonyabb száma az átlagosnál magasabb értékelési arányt mutat mind a települések, mind a turisztikai attrakciók tekintetében. Összességében elmondható, hogy a Pécs-Villány-Ős-Dráva kiemelt turisztikai fejlesztési térség esetében az adatok minimális eltérést mutatnak mind pozitív, mind negatív irányban, így egy kivételtól eltekintve átlagos képet mutat a desztináció. Az értékelések száma az ötödik legmagasabb a vizsgált térségek közül, tehát az aktivitás magas, de az átlagosnál több a kifogás a minőséget tekintve.

\subsection{SOPRON-FERTŐ TÉRSÉGE}

A Sopron-Fertő térség külföldi értékelési aránya jóval átlag feletti, ezzel együtt a kereskedelmi szálláshelyek külföldi vendégforgalma is igen magas, mely részarányát tekintve a második legmagasabb értéket mutatja a Szigetköz-Győr-Pannonhalma desztináció után. Az értékeléseknek mind az abszolút számai, mind az arányszámai elmaradnak az átlagostól, ennek ellenére a kereskedelmi szálláshelyi vendégforgalom mutatószámai messze meghaladják a többi térség hasonló értékeit, különös tekintettel a külföldi vendégforgalomra. A desztináció attrakció és település száma jelentősen alacsonyabb a többi régióhoz képest, így az átlagos értékelési adatoknak köszönhetóen az értékelt települések és attrakciók aránya magas. A térség magas vendégforgalmi, ezen belül is külföldi vendégforgalmi, adatokkal rendelkezik. Az attrakciók látogatószáma is igen magas, azonban átlagos értékelési jellemzőkkel rendelkezik. Mindezt az átlagosnál kevesebb településen és kevesebb attrakcióval érik el, ami viszont nem tükröződik a Tripadvior vendégértékelési számaiban.

\subsection{SZEGED- MAKÓ TÉRSÉGE}

A Szeged-Makó desztináció a második legjobb értékelt attrakció/értékelt település aránnyal rendelkezik a Debrecen és Hajdúszoboszló térség után. Amennyiben az értékelt attrakciókat a desztináció összes településszámával állítjuk arányba, úgy elsô helyezett holtversenyben a Bükk térséggel. Így elmondható, hogy a településszámhoz képest ez a térség rendelkezik a legtöbb értékelt attrakcióval. Az értékelések száma is meghaladja az átlagot, a minőség értékelése átlagos. A kereskedelmi szálláshelyi adatok kis mértékben átlag alattiak, ahogy az attrakciók látogatószáma is. A térségben található attrakciók és települések száma nagyon alacsony. Összességében elmondható, hogy nagyon kevés településsel és turisztikai attrakcióval csak minimálisan kevesebb forgalmi adatot produkál, illetve az átlagosnál magasabb értékelési számokat hoz a térség. Ez azt jelentheti, hogy a Szeged-Makó desztináció iránti érdeklődés messze meghaladja a turiszti- 
kai számokat, így ebben a térségben van az egyik legjelentősebb fejlődési potenciál.

\subsection{SZIGETKÖZ-GYŐR-PANNONHALMA TÉRSÉGE}

A Szigetköz-Győr-Pannonhalma térség a Tripadvisor adatok tekintetében minden szempontból elmarad az átlagoktól. Az egyetlen kivétel, hogy ez a térség rendelkezik a legmagasabb külföldi értékelési aránnyal, hisz az összes értékelés 85\%-a idegen nyelvú. Ez a jelentős külföldi érdeklődés a vendégforgalmi adatokban is megmutatkozik. A kereskedelmi szálláshely külföldi vendégrészesedése ebben a desztinációban a legmagasabb, az abszolút külföldi vendégforgalmi számokban pedig a Balaton után ez a legjelentősebb külföldiek által látogatott turisztikai desztináció az átlagnál némileg magasabb összes vendégszámmal. Ugyanez nem mondható el az attrakciók látogatószámáról, amely az átlagnak mindösszesen $60 \%$-át éri el. A térségben található attrakciók és települések száma 20-30\%-kal alacsonyabb a többi desztinációhoz képest. Összességében elmondható, hogy a térség leginkább a külföldiek számára releváns, akik nagyjából a térség 5 legjelentôsebb turisztikai attrakcióját keresik fel. A desztináció többi turisztikai attrakciója minimális érdeklődésre tart számot.

\subsection{TISZA-TÓ ÉS HORTOBÁGY TÉRSÉGE}

A Tisza-tó és Hortobágy térség minden Tripadvisor adat tekintetében messze elmarad az átlagtól, és ebben a térségben a legrosszabb a kiváló értékelések aránya. Kereskedelmi szálláshelyi vendégforgalma minimális, a külföldi részarány is kevesebb az átlagnál. Az attrakcióit felkereső látogatók száma is kevesebb, mint fele az átlagnak. Ezzel párhuzamosan a településszám és az attrakciószám csak minimálisan tér el a többi desztináció átlagértékétől, így ez nem magyarázza a kedvezőtlen adatokat, amelyek a Tisza-tavi Ökocentrumot leszámítva, a turisztikai attrakciók minőségi hiányaira vezethetóek vissza.

\subsection{TOKAJ-ZEMPLÉN TÉRSÉGE}

Az átlagosnál több település került értékelésre, ezzel együtt viszont kevesebb turisztikai attrakció, ami jól jellemzi a térség turisztikai dekoncentráltságát. A Mátra után ez a térség rendelkezik a legkisebb idegen nyelvú hozzászólási aránnyal. A kereskedelmi szálláshelyi adat harmada az átlagnak, a külföldi adatok még ennél is gyengébb részesedést mutatnak. Mind a települések, mind az attrakciók száma nagyjából a kétszerese a többi desztináció átlagának, a látogatószám mégis csak fele az átlagosnak. Az Ôrség után ez a térség rendelkezik a legalacsonyabb település/értékelés és attrakció/értékelés mutatószámmal. Összességében elmondható, hogy az átlagnál jóval több településen, sok turisztikai attrakcióval rendelkezik, amely viszont nem éri el sem az értékelók, sem pedig az utazók ingerküszöbét.

\section{Tripadvisor adatok szerinti desztinációs adatmegfeleltetések}

Összességében elmondható, hogy a keresleti oldal tekintetében a hazai turisztikai attrakciók kevésbé keresettek, használtak a Tripadvisor felületen. Az értékelések jellemzóen jók, viszont az értékelések száma igen csekély (1. ábra).

A nevesített és a még nem nevesített kiemelt turisztikai fejlesztési térségek attrakció értékeléseinek száma a Tripadvisor szerint

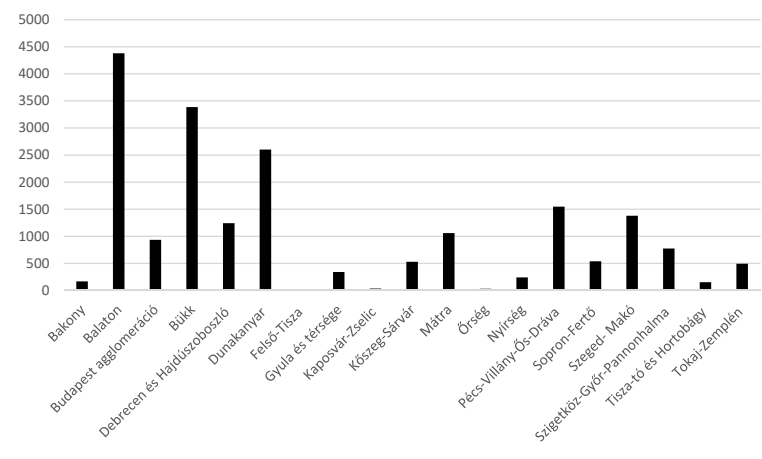

Forrás: saját szerkesztés

A Tripadvisoron a vendégek által legtöbbször értékelt attrakció a Bükk és a Balaton kiemelt turisztikai fejlesztési desztinációban található.

A legkisebb számmal a Kaposvár-Zselic, illetve a Nyírség és Felsố-Tisza térség jellemezhetô. Amenynyiben az értékelt/település és az értékelt/attrakció arányt vesszük figyelembe, azaz, hogy egy értékelt településre vetítve hol található a legtöbb értékelt attrakció, úgy a Debrecen és Hajdúszoboszló, valamint a Bükk térség áll az első két helyen, míg az utolsó helyeken a Kaposvár-Zselic és a Bakony szerepelnek.

Amennyiben viszont azt vizsgáljuk, hogy a kiemelt desztináció összes településéhez képest hol található a legtöbb értékelt attrakció, úgy a két, kevés településból álló, de országos vonzerôvel rendelkező térség áll az elsô két helyen: Debrecen és Hajdúszoboszló, illetve Gyula és környéke (2. ábra). 
2. ábra Sokkal érdekesebb viszont, hogy melyik két térség

Értékelt települések és attrakciók száma

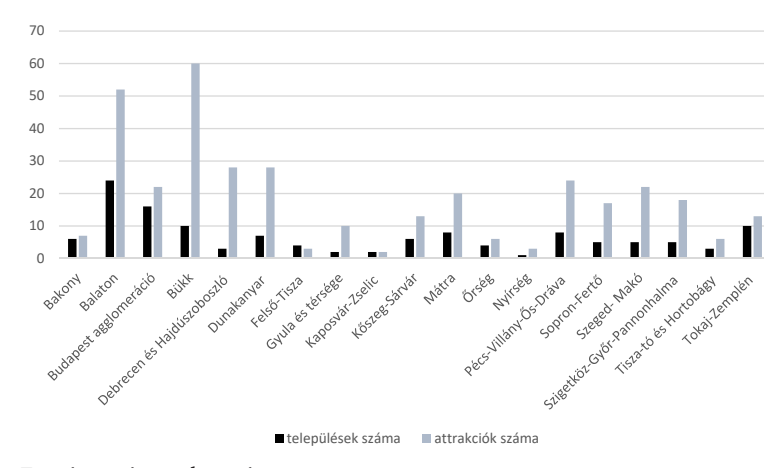

Forrás: saját szerkesztés áll az utolsó helyen, tehát melyik két térségben van szükség leginkább turisztikai termékfejlesztésre. Ez az Örség és a Felsó-Tisza.

Érdekes adatot mutat az egy értékelt attrakcióra jutó értékelések száma, tehát, hogy mely térség attrakciói érik el leginkább az értékelési ingerküszöböt. Ebben az esetben, nem túl meglepó módon, a Dunakanyar és a Balaton áll az első két helyen. A leginkább érdektelen térségek ezen szempont alapján a Felsô-Tisza és az Ôrség. Ez a mutatószám azt érzékelteti, hogy ebben a két térségben nemcsak nagyszabású turisztikai fejlesztés szükséges, hanem hogy az egyéb marketing eszközök igénybevétele mellett a márkaépítés is elengedhetetlen.

3. táblázat

\section{A kiemelt turisztikai fejlesztési térségek főbb jellemzői a Tripadvisor adatai alapján}

\begin{tabular}{|c|c|}
\hline desztináció neve & föbb jellemzói \\
\hline Bakony & $\begin{array}{l}\text { az átlagnál jóval kevesebb értékelt vonzerôvel és értékeléssel rendelkezik, a kereskedelmi szálláshelyek vendégforgalmi } \\
\text { adatai a Felsô-Tisza után a legalacsonyabbak, a külföldi vendégarány átlagos }\end{array}$ \\
\hline Balaton & $\begin{array}{l}\text { a legtöbb értékelt településsel és a második legtöbb (Bükk után) értékelt attrakcióval rendelkezik, a kiváló értékelések } \\
\text { száma magas }\end{array}$ \\
\hline $\begin{array}{l}\text { Budapest } \\
\text { agglomeráció }\end{array}$ & mind az értékelt települések számát, mind az attrakciószámot tekintve messze az átlag fölötti \\
\hline Bükk & $\begin{array}{l}\text { az értékelések átlagpontszáma a legalacsonyabb, a kiváló értékelések száma átlag alatti, a külföldi értékelések száma a } \\
\text { harmadik legmagasabb a desztinációk között }\end{array}$ \\
\hline $\begin{array}{l}\text { Debrecen és } \\
\text { Hajdúszoboszló }\end{array}$ & $\begin{array}{l}\text { kevés az értékelt település, viszont az értékelt attrakciók száma a duplája az átlagnak, az értékelések száma és a } \\
\text { külföldiek részaránya átlag feletti, az értékelési pontszámok átlagosak }\end{array}$ \\
\hline Dunakanyar & $\begin{array}{l}\text { a második legmagasabb részarányú külföldi értékeléssel és összességében a harmadik legtöbb értékeléssel rendelkezik, } \\
\text { az értékelések pontszáma átlagos }\end{array}$ \\
\hline Felsô-Tisza & minimális értékelt város és attrakciószámmal jellemezhető, és ezek pontszáma is alacsony \\
\hline Gyula és térsége & $\begin{array}{l}\text { a térség gyakorlatilag két várost tartalmaz, mind az értékelés átlagpontszáma, mind pedig a kiváló értékelések aránya } \\
\text { átlag közeli }\end{array}$ \\
\hline Kaposvár-Zselic & $\begin{array}{l}\text { minimális az értékelések száma, a Felső-Tisza és az Őrség után a legkevesebb, viszont ez a kevés értékelés a második } \\
\text { legmagasabb külföldi arányt mutatja, a Szigetköz-Gyôr-Pannonhalma térség után }\end{array}$ \\
\hline Kőszeg-Sárvár & külföldi értékelések száma átlagon felüli, viszont a pontszámok és a kiemelkedő attrakciók száma elmarad az átlagtól \\
\hline Mátra & $\begin{array}{l}\text { értékelési adatai megfelelnek az átlagnak, az átlagok tekintetében fontos kiemelni, hogy minimális a külföldi értékelések } \\
\text { száma, messze ebben a desztinációban a legmagasabb a magyar értékelői részvétel }\end{array}$ \\
\hline Örség & $\begin{array}{l}\text { a Tisza-tó és Hortobágy után a második legkevesebb a kiváló értékelések aránya, ezen kívül a külföldi értékelések } \\
\text { száma is kifejezetten alacsony }\end{array}$ \\
\hline Nyírség & $\begin{array}{l}\text { egy település három attrakciója került értékelésre, a külföldi részarány alacsony, viszont mind az értékelések } \\
\text { átlagpontja, mind a kiváló értékelések aránya a két legjobb a desztinációk között }\end{array}$ \\
\hline $\begin{array}{l}\text { Pécs-Villány-Ős- } \\
\text { Dráva }\end{array}$ & $\begin{array}{l}\text { az értékelő aktivitást mutató adatai az átlagnál minimálisan magasabb, a minóségi értékelések viszont minimálisan } \\
\text { alacsonyabb értéket mutatnak, átlagos képet mutat a desztináció, az értékelések száma az 5. legmagasabb }\end{array}$ \\
\hline Sopron-Fertô & $\begin{array}{l}\text { külföldi értékelési aránya jóval átlag feletti, a második legmagasabb értéket mutatja a Szigetköz-Gyôr-Pannonhalma } \\
\text { desztináció után, az értékeléseknek mind az abszolút számai, mind az arányszámai elmaradnak az átlagostól }\end{array}$ \\
\hline Szeged-Makó & $\begin{array}{l}\text { a második legjobb értékelt attrakció/értékelt település aránnyal rendelkezik a Debrecen és Hajdúszoboszló térség után, } \\
\text { a településszámhoz képest ez a térség rendelkezik a legtöbb értékelt attrakcióval }\end{array}$ \\
\hline $\begin{array}{l}\text { Szigetköz-Gyôr- } \\
\text { Pannonhalma }\end{array}$ & $\begin{array}{l}\text { minden adat tekintetében minden szempontból elmarad az átlagoktól, egyetlen kivétel, hogy ez a térség rendelkezik a } \\
\text { legmagasabb külföldi értékelési aránnyal, hisz az összes értékelés } 85 \% \text {-a idegen nyelvû́ }\end{array}$ \\
\hline $\begin{array}{l}\text { Tisza-tó és } \\
\text { Hortobágy }\end{array}$ & minden adat tekintetében messze elmarad az átlagtól, ebben a térségben a legrosszabb a kiváló értékelések aránya \\
\hline Tokaj-Zemplén & $\begin{array}{l}\text { az átlagosnál több település került értékelésre, ezzel együtt viszont kevesebb turisztikai attrakció, a Mátra után ez a } \\
\text { térség rendelkezik a legkisebb idegen nyelvú hozzászólási aránnyal }\end{array}$ \\
\hline
\end{tabular}


Amennyiben az értékelési aktivitást tovább bontva az attrakciók átlagos látogatószámát vesszük alapul és vetjük össze az értékelések számával, tehát azt vizsgáljuk, hogy egy térség egy turisztikai attrakciójának látogatóira hány értékelés jut, akkor a legaktívabb térség a Balaton, a Dunakanyar és Budapest agglomeráció, a legkevésbé aktív pedig a Kaposvár-Zselic, a Felső-Tisza és a Nyírség. Ez az arány mind attrakciófejlesztéssel, mind a marketing tevékenység bóvítésével javítható.

A Tripadvisor vendégértékelési adatai alapján, amelyet a kereskedelmi szálláshelyek vendégforgalmi adataival, illetve az MTÜ attrakciós adataival egészítettünk ki, a minden szempontból leginkább fejlesztési és marketing tevékenységet igénylő térség a Felsô-Tisza, melyet az Ôrség, a Kaposvár-Zselic és a Nyírség követ.

Attrakciófejlesztési szempontból az Ôrség, marketing szempontból pedig a Kaposvár-Zselic és a Nyírség igényel leginkább beavatkozást (3. táblázat).

A hozzászólások, kérdések esetében van olyan térség, ahol ez teljesen hiányzik, nem voltak hozzászólások és észrevételek. Jellemzően a Balaton és Budapest környéke az, ahol aktivitás tapasztalható a felületen, elsősorban a külföldiek részéról. Magyar nyelvú aktivitás a Bükk és a Mátra tekintetében jellemzó, a többi térség nem éri el a felhasználók ingerküszöbét. Ezzel párhuzamosan, néhány kivételtől eltekintve, a kínálati oldal sem érzi szükségességét az aktivitásnak, az évente beérkező néhány kérdésre ritka a válaszadás. Vélhetőleg nem érdemes külön munkavállalót alkalmazni, vagy más munkakörben dolgozó feladatait kiegészíteni a felületre beérkezó kérdések, értékelések kezelésére, fóleg nem idegen nyelvú kommunikációra. Mivel foglalási rendszer nem kapcsolódik az oldalhoz, így közvetlen bevételi előny, vagy hátrány nem származik az inaktivitásból. Összehasonlítva az oldal hazai aktivitását más, nemzetközi foglalási rendszerrel is ellátott, oldalakkal elmondható, hogy a hazai szolgáltatók az ilyen felületeken sokkal aktívabbak, a vendégvélemények száma pedig másfél, kétszerese a Tripadvisoron találhatóknak.

\section{Marketingkommunikáció}

A kiemelt térségek esetében elmondható, hogy a szolgáltatókra nem jellemző az attrakciók részérôl a Tripadvisor-on feltett kérdésekre történő hivatalos válaszadás. Több esetben a látogatók egymást segítik a kérdések megválaszolásával. Általában megállapítható, hogy még kérdések sincsenek feltéve az adott attrakcióhoz. Egyetlenegy térségrôl sem lehet elmondani, hogy a kommunikációja megfelelóen proaktív a Tripadvisor-on feltett kérdésekre vonatkozóan.

A Tripadvisor, mint interaktív turisztikai marketig-termék Magyarországon még nincs bevezetve. A hazai attrakciókat leginkább külföldi, "félhivatalos" utazók értékelik. Nemzetközi tendencia, hogy ezeknek a tapasztalt utazóknak a száma folyamatosan nó, ám Magyarország ettôl a trendtől még le van maradva. Ahhoz, hogy a hazai turisztikai attrakciók interaktív felületei élők és aktívak legyenek, az első lépést mindenképpen a turisztikai attrakcióknak kell megtenniük. Nem lehet arra várni, hogy a látogatók maguk kezdjék el használni a felületet.

Az attrakciólátogatások során rengeteg adat kerül az üzemeltetők birtokába a látogatókról, amelyek felhasználása Magyarországon még nem rendszeres. Ezeket az adatokat a Tripadvisor-on és a hasonló közösségi média felületeken történó promóciós tevékenységekhez mindenképpen fel kellene használni. Több turisztikai attrakció már a látogatás után elektronikus levélben megköszöni a látogatást. Számos esetben arra is van példa, hogy felhívják a figyelmet a Tripadvisor értékelésre. Olyan tapasztalat is van, hogy a látogatás során vagy a brosúrában, vagy külön papíron kérik az értékelést, esetleg az attrakció meglátogatása során használt elektronikus eszközök információi között kap szerepet az értékelésre történő felhívás.

Mivel a nemzetközi trendek azt mutatják, hogy a tudatos és tapasztalt utazók száma egyre nő, illetve az eddig megszokott barát és ismerős ajánlására történő utazások kiegészülnek az ismeretlenektől származó, a social média felületeken elérhető ajánlásokkal, a hazai turisztikai szolgáltatóknak mindenképpen követniük kell ezeket a változásokat. Mivel a hazai utazások körében még nem jelentenek releváns utazási motivációt az interaktív utazási portálok ajánlásai, ezt a lehetóséget mindenképpen az attrakcióknak kell termékként bevezetni. Folyamatosan szükség van a felhasználók és az értékelók számának növelésére, és az oldal élővé tételére. Mint minden bevezetendő termék esetében, szükség van a felhasználási motiváció növelésére esetleg nyereményjáték, vagy kedvezmény biztosítása révén. $\mathrm{Az}$ is megfontolandó, hogy az új turisztikai fejlesztések esetén kiemelten kellene foglalkozni az interaktív közösségi média felületek üzemeltetésével mind attrakciós, mind egységes turisztikai térségek szintjén. 


\section{Fejlesztési lehetôségek és következtetések}

\subsection{FEJLESZTENDŐ TERÜLETEK A TRIPADVISOR-I VENDÉGVÉLEMÉNYEK ALAPJÁN}

- Az online felületeken nem aktuálisak az információk az attrakciókról (például nyitva tartás, árak),

- az idegennyelv-tudás hiányzik vagy nem megfelelő szintú a szolgáltatók részérôl,

- az információk sokszor semmilyen formában nem elérhetőek idegen nyelven,

- hiányzik az alapinfrastruktúra,

- többször említésre került az épületek elhanyagoltsága,

- a szolgáltatásokat igénybe vevők csalódásukat fejezték ki az ár/érték arány tekintetében (a szolgáltatás színvonala nem arányos a magas belépóárral),

- barátságtalan, udvariatlan a személyzet,

- a fürdőkomplexumok esetében többször említésre került a nem megfelelő tisztasági állapot,

- az attrakciókban nem találhatóak étkezési lehetőségek, vagy ha igen, akkor alacsony minőségúek, viszont magas árfekvésúek,

- az attrakciókban az illemhelyiségek állapota nem megfelelö,

- fizetôs a parkolás és a parkolók zsúfoltak,

- leginkább pozitív véleményként Magyarország természeti szépségeit, értékeit nevezték meg.

Két téma különösen foglalkoztatja a kommentelőket. Pro és kontra hangoznak el érvek mind a családbarát turizmus, mind a kisvasutak esetében. A hazai helyzet megosztja a hozzászólókat:

- családbarát turizmus:

- pro: sok komment szól arról, hogy a gyermekek számára ideális az attrakció elérhetôek például gyermekmedencék, gyermekbarát szolgáltatások, kapcsolódó élmények családdal.

- kontra: túlzott gyerekzaj, túl sok a gyerek, akik miatt a medence és környezete kikapcsolódásra alkalmatlan.

- kisvasút:

- pro: vonatozás élménye, természetközeliség.

- kontra: ár-érték arány, színvonal alacsony minősége, nem megfelelő megközelíthetőség.

\subsection{HORIZONTÁLIS BEAVATKOZÁSI TERÜLETEK A NEMZETI TURIZMUSFEJLESZTÉSI STRATÉGIA (NTS) 2030-BAN}

Nemcsak a statisztikai adatok feleltethetőek meg a Tripadvisor elemzése során nyert információknak. A Magyar Turisztikai Ügynökség által készített, és a Kormány által elfogadott NTS 2030 dokumentum célrendszerének horizontális beavatkozási területei is egyezést mutatnak a Tripadvisor hazai desztinációkat érintő kommentjeivel, értékeléseivel és elvárásaival:

- H1. Együtt-élő turizmus: Célja a helyi közösségekkel és a természeti környezettel harmonikusan együtt élő turizmus megvalósítása. Több komment is kiemelten fontosnak tartja ezt a területet, megállapítva, hogy az adott térség helyi közössége és szolgáltatásai nélkül nem teljes a turisztikai élmény: „A magas bérleti díjak miatt üres üzlethelyiségek az utca mentén, télen nem takarítják az utcát, az üzlethelyiségek üresek, zárva vannak nyáron is." Ezen kívül kiemelésre kerül a helyi termelők és termékek szerepének fontossága: „a helyi ételeket kipróbálni".

- H2. Családbarát turizmus: Célja több generáció közös élményszerzését lehetővé tevő turisztikai attrakciók megvalósítása, a szálláshelyek, vendéglátóhelyek és a közlekedési infrastruktúra családbarát szempontoknak megfelelő fejlesztése. A családbarát szolgáltatások rendelkezésre állása, használhatósága az egyik legnagyobb témaköre a hozzászólásoknak. Ezeknek a megléte, magas szintú üzemeltetése, illetve egyedi módon történó kibóvítése plusz utazási motivációt jelent az utazóknak: „Nyugati színvonalú sípálya, gyerekes családok számára is szuper hely, kutyával is látogathatóak a pincék, gyermek élménypark, családbarát; Maya játszóteret a gyermekes családok pozitívan értékelik, Csodás kinti és benti gyerekmedencék, a kinti megfelelően árnyékolt."

- H3. Hozzáférhetô turizmus: Célja a fizikai és infokommunikációs akadálymentesítés, illetve az attrakciók közvetlen megközelíthetőségének fejlesztése. Ez a másik nagy témakör, amelynek megléte és színvonala kiegészítő motivációt biztosít a potenciális utazók számára, hiánya viszont jelentősen rontja az utazási élményt: „korlátozott mozgásképességúként - taxi vitt fel bennünket. Nem csoda hát, hogy családtagjainkkal - balatoni nyaralásunk 
során - szerettük volna feleleveníteni kellemes élményeinket, a mozgássérült mosdó belülről nem zárható."

- H4. Érthetô turizmus: Célja következetes, informatív tájékoztatás, illetve a többnyelvúség megfeleló megvalósítása. A Tripadvisor kommentek ebben a témában mutatják a legnagyobb hiányosságokat. Elhanyagolható a pozitív kommentek száma. Az utazás az otthon elhagyásától a visszaérkezésig tart. Az oda út is már a turizmus része, így ezeket a szempontokat is különös figyelemmel kell kezelni: „csak készpénzzel lehet fizetni a belépőt!” „A park viszonylag rendezett azonban a kevés pad elhanyagolt, kevés információs tábla van elhelyezve, kevés az információs tábla és az is csak magyarul."

- H5. Digitális turizmus: Célja a digitális technológiák alkalmazása, a bennük rejlő lehetôség kiaknázása a turizmus valamennyi aspektusában. A digitális technika megléte ma már alapfeltétele a turisztikai szolgáltatásoknak, legyen szó akár ingyenes wifiról, elektronikus információs táblákról, vagy digitális bemutató eszközökről. Éppen ezért a külföldi kommentek általában ezeknek a hiányát említik, a belföldi utazók emelik ki csak pozitívumként: "Interaktív és érdekes tárlatvezetés, planetáriumi vetítés, van wifi, nem eléggé interaktív."

A nevesített és a még nem nevesített kiemelt turisztikai fejlesztési térségek attrakcióihoz történó külföldi hozzászólások aránya

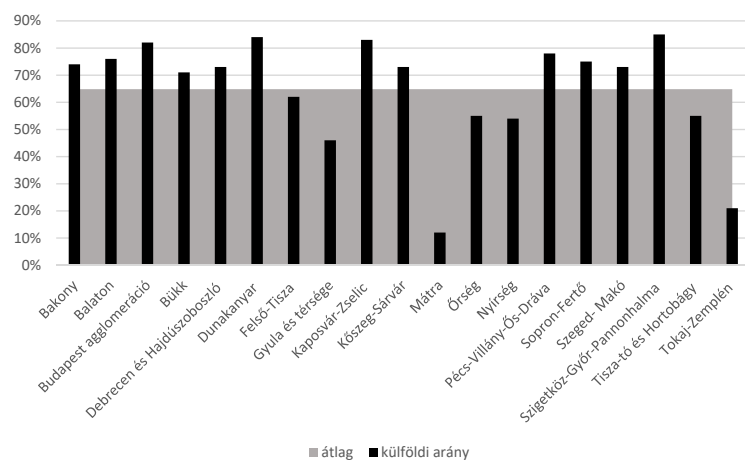

Forrás: saját szerkesztés

A Tripadvior szubjektív jellemzőiből képzett adatbázis statisztikái több esetben is megfeleltethetőek a hazai turisztikai mérőszámoknak. Természetesen egy minden szempontból elfogadható elemzéshez nem megfeleló ez az adathalmaz, de trendeket, irányokat és jellemzóket nagy biztonsággal meg lehet határozni. Amennyiben több hasonló portál adatai is feldolgozásra kerülnének, úgy ezek a megállapítások még pontosabbá válhatnának. Ami a Tripadvisor tanulmány adatai alapján nagy biztonsággal elmondható a hazai turisztikai piacról, hogy hazánk jelenleg sem szolgáltatói, sem felhasználói szinten nem éri el a nyugat-európai vendégkommentelési, vendégértékelési szintet. A külföldi hozzászólások aránya (3. ábra) a hazai turisztikai attrakciók tekintetében messze meghaladja a magyar hozzászólásokat (kiszûrésre kerültek a magyar személyek idegen nyelvû́ hozzászólásai).

\section{4. ábra}

A nevesített és a még nem nevesített kiemelt turisztikai fejlesztési térségek értékeléseinek átlagpontszáma

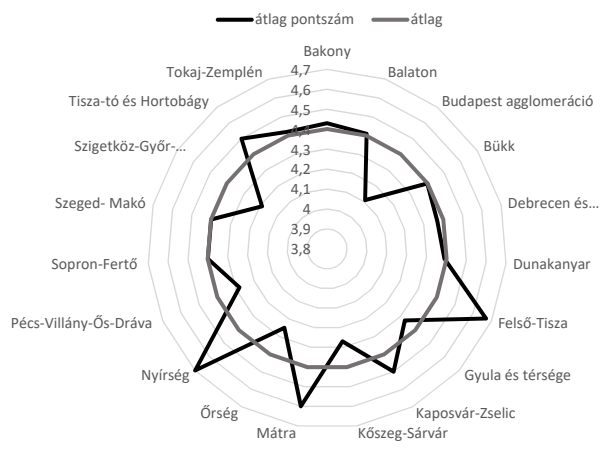

Forrás: saját szerkesztés

A hazai attrakciók átlagpontszáma az 5-ös skálán 4,4 pont alacsony szórás mellett. A térségek átlagpontszámai sem a kutatás során vizsgált $\mathrm{KSH}$ $(\mathrm{r}=-0,15)$, sem az MTÜ adataival $(\mathrm{r}=0,0)$ nem mutatnak korrelációt, így következtetések levonására ebben a tekintetben nem alkalmasak, viszont a desztinációk egymás közötti kapcsolatát, az egymáshoz viszonyított rangsorát jól jellemzik (4. ábra).

A többi adat elemzése során megállapítható, hogy az értékelők és hozzászólók véleménye hasonlóságot mutat a szakma által is megfogalmazott kritikákkal, illetve pozitívumokkal. Több esetben is megfeleltethetốek a vélemények az NTS-ben megfogalmazottakkal, amelyeket megerősítenek, illetve kiegészítenek. Segít továbbá a problémák priorizálásában, illetve a kiemelt turisztikai fejlesztési térségek fejlesztési és marketing koncepciójának fókuszpont meghatározásában.

A vendégelégedettség és komment általánosságban még nem jelent utazási motivációt a potenciális utazók tekintetében, ám a speciális indíttatásból utazók kivételt képeznek, akik sokszor a hasonló beállítottságú emberek véleménye alapján választják ki a desztinációt. Összességében 
elmondható, hogy a szubjektív vélemények, hozzászólások inkább csak orientálnak a helyszinek, desztinációk kiválasztásához, illetve az utazási döntést megerôsító funkciójuk van. A barátok ajánlása eddig is kiemelten fontos volt az utazási döntés folyamata során. Ezt egészítheti ki, illetve a késôbbiekben ezt a szerepet veheti át az "idegenek" on-line ajánlása, véleménye.

Marketing szempontból a közösségi utazási portálok szerepe egyre fontosabb, bár Magyarországon még nem meghatározó. Ennek ellenére biztosra vehető, hogy a megszokott marketing eszközök mellett (helyett) a jövőben mindenképpen kiemelt szerepet fog játszani ez a platform. Az elmúlt évek, évtizedek tendenciáinak sorát (utazási iroda - saját foglalás, klasszikus légitársaság fapados járatok, szálloda - airbnb, hirdetés - blog eltolódás) ez a szubjektív, de összességében trendszerûséget mutató vendégértékelő módszer is erősíteni fogja, illetve beleilleszkedik, mint az utazási piac egyik meghatározó közösségi, élményértékelő-visszajelző szereplője. 